\title{
Anticancer activity of novel soursop leaves active compound (SF- 1603) through apoptotic induction in liver cancer
}

\author{
Maya Tejasari a, ${ }^{*}$, Herri Sastramihardja ${ }^{b}$, Siti Aminah Abdurachman ${ }^{b}$, Dwi Prasetyo ${ }^{c}$ \\ a Faculty of Medicine, Bandung Islamic University, Indonesia \\ ${ }^{b}$ Faculty of Medicine, Padjadjaran University, Indonesia \\ c Pediatric Department, Faculty of Medicine, Padjadjaran University, Indonesia \\ *Corresponding author: mayatejasari4981@gmail.com
}

\section{Article history}

Submitted 27 February 2018

Revised 28 March 2018

Accepted 30 April 2018

Published Online 4 June 2018

\begin{abstract}
There are no effective standard treatments for unresectable stage of liver cancer have been established. These insights lead the pursuit of targeted therapeutic strategies for reactivating apoptosis to eradicate cancer cells. It was hypothesized that active compound in the soursop leaves will be able to induce apoptosis. Objective of the study is to explore the role of novel soursop leaves active compound (SF-1603) in apoptosis induction to find a new agent for liver cancer therapy. This study was use HepG2 cell line culture seeded in DMEM / F12. There were control group and 3 intervention group given SF-1603 with different concentration. Apoptosis detection was done using Terminal deoxynucleotidyl Transferase-mediated dUTP Nick End Labeling (TUNEL) method. Statistical analyses were conducted using linear regression. The result showed the cells undergoing apoptosis in the control group less than treatment groups. There was a strong positive correlation $(r=0.847)$ between the rate of apoptosis and a concentration of SF-1603, reflected the apoptotic effect with a dose-dependent manner. The study conclude, the novel soursop leaves active compound SF-1603 had the strong ability to induce apoptosis on liver cancer cell line culture, so it can be used as a candidate for new agent for liver cancer therapy.
\end{abstract}

Keywords: Apoptosis, liver cancer, soursop (Annona muricata) leaves, targetted therapy.

\section{INTRODUCTION}

Hepatocellular carcinoma (HCC) is a type of cancer most commonly found in the liver. The disease is one of the most common types of cancer in the world and among the many causes of death. HCC high mortality rate occurred because patients generally come with advanced stage. Recommended therapy for HCC with advanced stage is the palliative treatment in the form of chemotherapy (Bruix \& Sherman, 2005; Sherman et al., 2011; Spengler, 2012). Chemotherapy is still the best option for patients with advanced HCC, however until now the effectiveness of chemotherapy in patients with HCC remains poor (Ghassan \& Abou-alfa, 2004; Ho et al., 2009; Huynh et al., 2010; Lencioni et al., 2008; Tejasari et al, 2016; Park et al., 2006; Robotin et al., 2009; Wirth et al., 2005).

Although many chemotherapeutic agents have been tested, the role of systemic chemotherapy for hepatocellular carcinoma (HCC) remains unclear. New therapeutic strategies with more targeted therapy are needed to improve treatment effectiveness (Ghassan \& Abou-alfa, 2004; Park et al., 2006). Currently there are no prospective controlled studies have demonstrated that systemic chemotherapy prolongs the survival of HCC patients when compared with supportive care (Ghassan \& Abou-alfa, 2004; Park et al., 2006; Wirth et al., 2005). Therapeutic strategies based on the molecular target through signal transmission intervention and apoptosis regulation, offering new hope for more effective treatment options (Ghassan \& Abou-alfa, 2004; Wirth et al., 2005). Carcinogenesis occurs in HCC can be used as the basis of interventions on mechanism pathway may have potential as therapeutic targets. One potential target for HCC therapy that has not been widely studied is the path through the mechanism of apoptosis, whereas in the carcinogenesis of HCC occurs apoptosis dysregulation so this pathway is a potential to be developed.

Understanding of genetics and treatment has made much progress, but HCC remains a deadly disease to day. Further studies are needed to identify new therapeutic agents who have more potent activity against this liver cancer. Further research steps including additional clinical studies should be undertaken on new chemotherapy target agents, either single or in combination with effective chemotherapy effects (Ghassan \& Abou-alfa, 2004; Park et al., 2006; Wirth et al., 2005).

Apoptosis is a mechanism of programmed cell death induced by the intracellular controlled program. In apoptosis process, cells that should die activates proteolytic enzymes (Albert et al, 2002; Chang et al, 2000; Kumar et al, 2003; Lu et al, 2005; Tejasari et al, 2014; Yuniarti et al., 2014)

Apoptosis plays a role in suppressing the progression of liver disease, either through the intrinsic and extrinsic pathway, as well as 
disorders of the mitochondria (He et al., 2010; Liu et al., 2011; Tejasari et al, 2016; Tejasari et al,, 2013).

Natural materials are a source of potential therapeutic agents that have many advantages; easily available, inexpensive, and has minimal side effects (Lee et al., 2001). Compounds derived from natural materials have anti-tumor properties. Indonesia is known to have many natural ingredients that are trusted by the community to prevent and even treat cancer, one of which is Annona muricata Linn generally known as soursop (Adewole S \& J., 2009; Lee et al., 2001; Martin, 2006; Song et al, 2014; Yildiz et al, 2008).

Almost all parts of the soursop plant morphology have been reported to have uses in traditional medicine, but has not done a lot of scientific research to examine in detail what kind of substances that exist in each part of the soursop plant that has an active property (Adina et al., 2009; D'Archivio, Santangelo, Scazzocchio, Varì, \& Filesi, 2008; Fajarningsih, Nursid, Wikanta, \& Marraskuranto, 2008; Muharni, Supriyatna, Husein, Bahti, \& Dachriyanus, 2009). Studies conducted between 1995 and 2011 showed that the active ingredient of soursop leaves has a strong antitumor activity in various types of cancer cell lines. Other studies have also reported that the active ingredients of soursop leaves proved capable of inducing apoptosis, but studies of soursop leaf ability in inducing apoptosis in liver cancer cells and mechanisms of action have not been widely performed (Coloma et al, 2002).

This study aims to explore the capabilities of the new pure compound (SF-1603) were isolated from the soursop leaves in apoptosis induction of liver cancer cell, so that can be used as a new agent candidate for the treatment of patients with liver cancer.

\section{LITERATURE REVIEW}

Cancer occurs because of fundamental changes in cell physiology that eventually grows uncontrolled and has the following general characteristics: (1) independent in growth signals, (2) insensitive to growth signals, (3) avoiding apoptosis, (4) Unlimited potential replication, (5) angiogenesis, and (6) invasion and metastasis to other tissues, therefore anticancer development targets are directed to apoptosis induction (Cha \& DeMatteo, 2005; Ho et al., 2009) inhibition of angiogenesis especially for solid cancers such as breast cancer, growth factor as well as growth factor signals that regulate the cell cycle, and checkpoint control (Cha \& DeMatteo, 2005). Cancer can be seen as a complex cellular phenotype associated with unlimited replicative potential, unbound to growth signals and parallelly resistant to inhibition of growth signals, avoiding cell death, sustained angiogenesis, and invasive tissue and metastasis capabilities (Hanahan $\&$ Weinberg, 2000; Steeg, 2006). Malignant tumors are invasive and can metastasize to distant places through the circulatory system. As a result, the main cause of death of this cancer is the spread of metastasis, not the primary tumor itself (Steeg, 2006). Neoplastic cell accumulation can occur not only because of oncogen activation that promotes tumor growth or inactivation of tumor suppressor genes that suppress growth but also because it is dysregulated in genes that control apoptosis. As cell growth is controlled by growth genes and growth suppressants, cell survival is also controlled by genes that drive and inhibit apoptosis.

Hepatocarcinogenesis is a slow process genomic changes that progressively alter the hepatocellular phenotype and produce cellular intermediates that develop into hepatocellular carcinoma. During a long period of prenoplastic, which often occurs in liver tissue infected with chronic hepatitis, cirrhosis or both, there is a change of hepatocyte accelerated by the stimulation of a partial mitogenic pathway through an epigenetic mechanism. This condition causes the production of monoclonal hepatocyte populations that are distorted and dysplasia in the form of telomerase erosion, telomerase reexpression, microsatellite instability, and occasionally structural deviations in genes and chromosomes. The development of dysplastic hepatocytes in the form of focus and nodules as well as the emergence of hepatocellular carcinoma is associated with the accumulation of irreversible structural changes in genes and chromosomes, but the base of the malignant phenotype genome is heterogeneous. Malignant phenotype of hepatocytes is caused by disruption of a number of genes that function in different pathways resulting in hepatocellular carcinoma with different molecular variants (Cha \& DeMatteo, 2005; Thorgeirsson \& Grisham, 2002).

The process of HCC is almost always developed in liver tissue that has chronic hepatitis or cirrhosis that is the condition of many deaths hepatocytes, inflammatory cells invade liver tissue and there is a lot of connective tissue deposition on liver tissue. This change drastically alters the matrix and microenvironment of the liver tissue (Cha \& DeMatteo, 2005; Thorgeirsson \& Grisham, 2002). Hepatocellular changes which are early predictions of HCC, are the discovery of hepatocyte focuses that have been phenotypically altered and partial discovery of hepatocytes with dysplasia that form the focus and nodule (Thorgeirsson \& Grisham, 2002). During prenoplastic periods ranging from 10 to 30 years, there is interference with the expression of various genes quantitatively without changes in the structure of genes and chromosomes. Increased expression of transforming growth factor- $\alpha$ (TGF- $\alpha$ ) and insulin growth factor-2 (IGF-2) play a role in accelerating proliferation in hepatocytes (Chiu et al., 2003)

Currently there are many researches to find effective treatments for HCC is still being developed. Curative approaches such as surgery and transplantation can only be done in a limited way due to various causes such as less donors and considering their effect on liver function. The recommendation of therapy based on the Barcelona Clinic Liver Cancer (BCLC) classification for advanced stage HCC is by palliative approach in the form of systemic chemotherapy. Curative approaches such as resection and transplantation can only be limited to people with early-stage HCC. Chemotherapy is still the best choice for patients with advanced HCC, but until now the effectiveness of chemotherapy in patients with HCC also still remain in the debate, instead often judged relatively ineffective. Treatment options for HCC patients are still very limited this is also one of the reasons for this liver cancer prognosis remain poor (Bruix \& Sherman, 2005; Ghassan \& Abou-alfa, 2004; Ho et al., 2009; Huynh et al., 2010; Lencioni et al., 2008; Park et al., 2006; Robotin et al., 2009; Sherman et al., 2011; Wirth et al., 2005).

Systemic chemotherapy is relatively ineffective in HCC. Hepatocellular carcinoma is resistant to chemotherapy because of the high mutation load and also the mechanism of drug resistance. The resulting resistance mechanism is associated with low-dose chemotherapy as it considers liver dysfunction and is also performed to reduce toxicity (Ghassan \& Abou-alfa, 2004; Park et al., 2006; Wirth et al., 2005). Understanding of genetics and treatment has made much progress, but HCC remains a deadly disease to day. Further studies are needed to identify new theurapetic agents who have more potent activity against this liver cancer (Park et al., 2006). Further research steps including additional clinical studies should be undertaken on new chemotherapy target agents, either single or in combination with effective chemotherapy effects (Ghassan \& Aboualfa, 2004; Park et al., 2006; Wirth et al., 2005).

Apoptosis is a mechanism of programmed cell death induced by the intracellular controlled program. In apoptosis process, cells that should die activates proteolytic enzymes. Apoptosis plays a role in suppressing the progression of liver disease, either through the intrinsic and extrinsic pathway, as well as disorders of the mitochondria (He et al., 2010; Liu et al., 2011; N. S. Maya Tejasari, Herri S Sastramihardja, Djanuarsih Iwan, 2014; Yuniarti et al., 2014).

Apoptosis is induced by a cascade of sequences of molecular events that are likely to be initiated through multiple pathways that will eventually activate caspase enzymes. Too much or too little apoptosis can underlie several types of diseases such as degenerative diseases and cancer. From many studies of apoptosis it has finally identified specific genes (ced genes) that initiate or inhibit apoptosis (Irene et al., 2005; Kumar et al., 2003; Wong, 2011). The process of apoptosis can be divided into two phases as follows (Kumar et al., 2003; Martin, 2006):

1) Initiation phase, when caspase enzymes catalyzed to become active 2) Phase of execution, when the caspase enzyme causes cell death

The initiation of apoptosis occurs because signals from extrinsic pathways (receptor initiation paths) and intrinsic pathways 
(mitochondrial pathways). Both of these pathways ultimately activate the caspase enzyme and relate to each other at several stages.

\section{Extrinsic Pathway (Death Receptor-Initiated Pathway)}

This signal path is initiated by a death receptor bond on the cell surface with its ligand. Cell mortality receptors are part of a group of tumor necrosis factor (TNFs) family that have cytoplasmic domains involved in protein interactions called death domains because they play a significant role in the delivery of apoptotic signals. The most widely recognized death receptors are tumor necrosis factor- 1 receptor (TNFR1) and Fas protein (CD95) (Kumar et al., 2003; Martin, 2006; Wirth et al., 2005).

Apoptosis through this pathway can be inhibited by a protein called FLICE (FADD-like IL-1 $\beta$-converting enzyme) -inhibitory protein ((FLIP), which binds to pro-caspase 8 so it can not release or activate enzymes because it has no enzymatic activity. Several types of viruses and normal cells can produce FLIP and use this protein inhibitor to protect normal cells or infected cells, from apoptotic processes through Fas induced pathways (Kumar et al., 2003; Martin, 2006; Wirth et al., 2005). The mechanism of apotosis induced by this death receptor can be seen in Fig. 1.

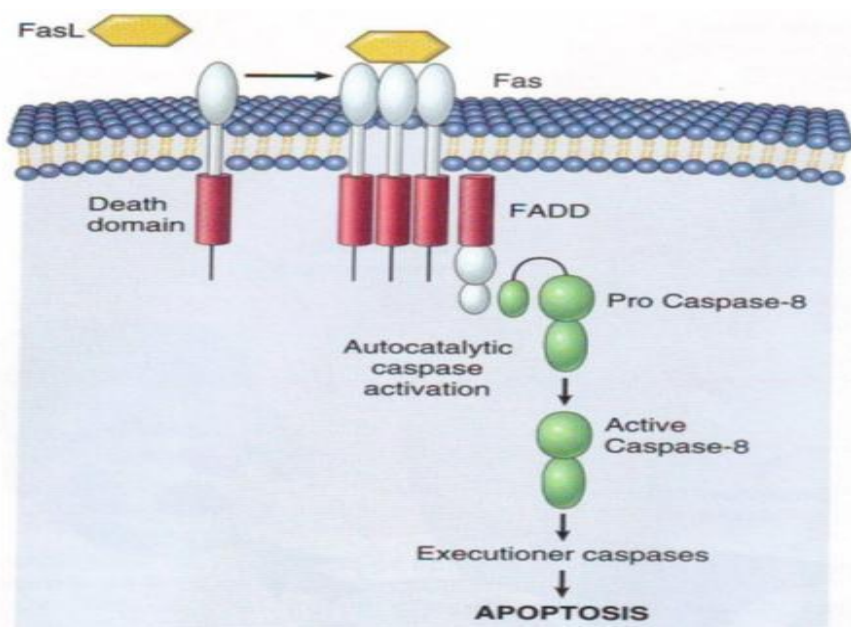

Fig. 1 Initiation of Apoptosis through Extrinsic Pathway (Kumar et al., 2003).

\section{Intrinsic Pathway (Mitochondrial Pathway)}

This apoptotic pathway results from increased permeability of the mitochondria and the release of proaptoptotic molecules into the cytoplasm, without the involvement of the death receptor. Several growth factors and other survival signals stimulate the production of antiapoptosis from the $\mathrm{Bcl}-2$ protein class. This group of proteins is identified as oncogenes in B-cell lymphoma and homologous with C.elegans protein (Ced-9) (Cagle \& Allen, 2009; Kumar et al., 2003; Martin, 2006; Wirth et al., 2005). There are more than 20 proteins belonging to this class that all contribute to the regulation of apoptosis. The two proteins that are the main antiapoptosis are Bcl-2 and Bcl-x proteins. Both of these antiapoptosis proteins are normal in mitochondrial membrane and cell cytoplasm. When cells receive survival or stress signals, Bcl-2 and / or Bcl-x disappear from the mitochondrial membrane and are replaced by proapoptotic proteins such as Bak, Bax, and Bim.5 (Cagle \& Allen, 2009).

When the levels of Bcl-2 and / or Bcl-x decrease, the permeability of the mitochondrial membrane will increase so that some proteins that can activate the caspase cascade are released. One of these proteins is cytochrome c, which is known to play a role in mitochondrial respiration. In the cytosol, cytochrome $\mathrm{c}$ binds to a protein called apoptosis activating factor-1 (Apaf-1) that is homologous to Ced-4, and this complex activates caspase 9. Bcl-2 and Bcl-x may also directly inhibit the activation of Apaf-1 So that in the absence of Bcl-2 and Bcl-x there may be activation of Apaf-1 (Cagle \& Allen, 2009).

Other mitochondrial proteins such as Apoptosis Inducing Factor (AIF) may enter the cytoplasm and bind to the protein inhibitor to be neutral and inhibitory of caspase activation. The result is a caspase cascade initiation process. It can be concluded that the essence of this interstitial pathway is a balance between proaptoptotic molecules and protective molecules that control the mitochondrial permeability as well as the release of factors that induce cell death that under normal circumstances reside in the mitochondria (Albert \& Johnson, 2002; Cagle \& Allen, 2009; Kumar et al., 2003). The mechanism of apoptosis initiated through this intrinsic path can be seen in Fig. 2.

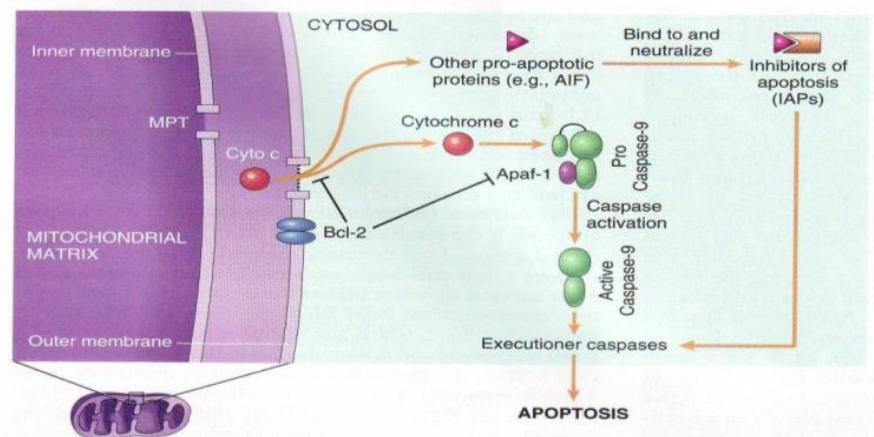

Fig. 2 Initiation of Apoptosis Through the Intrinsic Path (Kumar et al., 2003).

The execution phase of apoptosis is mediated by proteolytic cascade that will initiate various mechanisms. Protein caspase group consists of more than 10 members who are functionally divided into two groups namely the initiator and executor (Cagle \& Allen, 2009; Cardoso et al., 2010; Lee et al., 2001; Yildiz et al., 2008). Caspase be in the form of inactive proenzyme or zymogen, and must first be activated to be able to initiate apoptosis. Caspase have a site activation of its own which can be hydrolyzed not only by others caspase but also by itself through the process autocatalytic. Initiated caspase transformed into an active form and will activates others caspase. Executor caspase that active in many cellular components, break down cytoskeleton and matrix proteins of the cell, causing damage of the cytoskeleton and destruction of the cell nucleus. The target of caspase activity are proteins in cell nucleus that play a role in the process of transcription, DNA replication and DNA repair. At the same time, activation of caspase- 3 would result in a change DNAase into the active form that will induce internucleosomal resulting DNA fragmentation (Cagle \& Allen, 2009; Cardoso et al., 2010; Yildiz et al., 2008).

Although there are variations which are not visible, there is a morphological apoptotic feature that shows the principal patterns those can be generally applied to all apoptosis types (Bassiouny et al., 2008; Cagle \& Allen, 2009; Cardoso et al., 2010). Morphological description begins with cell shrinkage. Cell size becomes smaller, the cytoplasm becomes more dense, while the organelles seemed arranged more tightly. Furthermore, chromatin condensation occurs which is the most common characteristic of apoptosis. Core chromatin condenses to form aggregation in peripheral under the nuclear membrane, form the solid mass demarcated in different shapes and sizes. The core can be split into two or more fragments, then quickly formed buds and cytoplasmic fragments into apoptotic bodies consisting of cytosolic vesicles and organelles wrapped by a membrane (Cagle \& Allen, 2009; Cardoso et al., 2010; Lee et al., 2001; Yildiz et al., 2008).

The morphological appereance of cells undergoing apoptosis running in a time sequence with the initial process occurs in a short time, while the final stage involving lysosomal degradation and fragmentation of DNA usually occurs in a longer process (Cagle \& Allen, 2009; Park et al., 2006).

Annona muricata Linn (Annonaceae) is commonly known as soursop or graviola. Annona muricata is categorized as a "custardapple" plant in the Annonaceae family and is a vertical deciduous plant about 5-9 meters high with open and circular trunks (Arnasati, 2010; Santi, Soetarno, \& Kusmardiyani, 2007).

Soursop is a plant that comes from the Caribbean, Central America and South America. This plant is grown commercially for its meat fruits. This plant can grow in any place and is best grown in a 
fairly watery area. In Indonesia soursop can grow well at an altitude of $1,000 \mathrm{~m}$ above sea level. Soursop name itself comes from the Dutch zuurzak which means a sour sac. This soursop tree can reach a height of up to 9 meters (Shiddiqi, Rindiatuti, \& Sri, 2008; Wu et al., 1995).

The local name in Indonesia for soursop fruit is quite diverse among them in Java called jackfruit sabrang or jackfruit, in the Sundanese region called jackal walanda, in Madura called jackfruit buris, in Bali called srikaya jawa, in Aceh called deureuyan dutch, in Nias called durio Ulondro, in Minangkabau called durian betawi, in Lampung called jambu landa (Arnasati, 2010).

Habitat of soursop plants is widespread throughout Indonesia. Soursop leaf contains include acetogenin compounds, essential oils, reticuline, loreximine, coclaurine, annomurine, and higenamine. Soursop fruit contains many carbohydrates, especially fructose and other nutrients such as vitamin $\mathrm{C}$, vitamin $\mathrm{B} 1$, and vitamin $\mathrm{B} 2$ are quite a lot. Soursop seed is toxic and can be used as a natural insecticide, as well as srikaya seed (Irene et al., 2005; Martin, 2006; Song et al., 2014). Soursop leaf is known to be useful in inhibiting cancer cells by inducing apoptosis, antidiare, analgesic, antidisentri, antiasma, anthelmitic, blood vessel dilation, stimulates digestion, and reduces depression (Arnasati, 2010; Santi et al., 2007).

The Annona muricata plant originally came from America, but the plant has been naturalized and is grown in tropical areas and is consumed by humans, primarily to overcome parasitic infections and cancer. This plant is also widely used in Africa as a sedative and antispasmodic. In the tropics of Africa including Nigeria, the plant is used as an antiparasit, antispasmodic, astringent, anticancer, sedative, antihypertensive, insecticide, pesticide, vermifuge, as well as for cough, fever, pain and skin diseases. The bark and root of this plant are commonly used to treat diarrhea, dysentery, and worm infections. The flesh is also used to treat fever. Unpeeled fruit is used as astrigen and is used to treat intestinal atony and scurvy disease. In India, both root, bark and plant leaves are used as antihelminth, while the flowers and flesh are used to treat cataracts (Arnasati, 2010; X. Lu et al., 2005; Santi et al., 2007).

Various chemical compositions have been isolated from various parts of soursop plants such as roots, bark, leaves, fruit flesh, and seeds. Some of the phytochemicals reported to have been isolated and characterized from various parts of soursop plants are annonaceous acetogenins, lactones, isoquinoline alkaloids, tannins, coumarins, procyanidins, flavonoids, pentacyclic terpenoid saponins, $\mathrm{p}$-coumaric acid, myristic acid, stepharine, reticuline, ellagic acid, phytosterol (Bsitosterol, stigmasterol), sugars, alcohols, aldehydes, organic and nonorganic acids, metals, inorganic salts, vitamins B and C, GABA, annonacin, annocatalin, annomominicin, annomuricin, annomuricatin, corossolon, epomuricinin, gigantetrocin, javoricin, Muricine, muricinine, muricapentocin, muricoreacin, montanacin, montecristin, muracin, muracicatalin, muricolin, robustocin, solamin, and others (Arnasati, 2010).

Although there are many elements contained in soursop plants, only a few pure compounds that many explored its potential as an anticancer, one of which is acetogenins. Annonaceous acetogenin is a large phytochemical group isolated from the family plant of the annonaceae and naturally contains a polymer having activity as an anticancer. Polyamide is a secondary metabolite of bacteria, fungi, plants, and animals. The polyetides are biosynthesized by decarboxylative condensation from the malonyl-CoA unit in the same process as fatty acid synthesis (Claisen condensation). The polymeride chain is produced by polymeride synthase and is modified into a bioactive natural product. Structurally polyketide is a very large group of diverse natural products with diverse biological activities and pharmacological properties. Polyzidides are divided into three classes: type I polymer which is a macrolides produced by multimodular megasynthases, type II polymeride which is an aromatic molecule produced by the action of dissociated iterative enzymes, and polyamide type III which is a small aromatic molecule produced by the fungal species. Polyamide has antibiotic, antifungal, cytostatic, anticholesterol, antiparasitic, coccidiostats, and is a natural insecticide (Coloma et al., 2002; Villo, 2008).
Natural polyphenols are a large group of compounds derived from plants, which are chemically structured by two or more phenol units (Dai \& Mumper, 2010; Fraga \& Oteiza, 2011). Some chemists recognize the term polyphenols as White-Bate-Smith-Swain-Haslam definition described in several characteristics: (Ii) has a molecular weight of 500-4000 Da, (iii) has> 12 phenolic hydroxyl groups, and (iv) has 5-7 aromatic rings per 1,000 $\mathrm{Da}$, the limits of this range are flexible (Quideau, Deffieux, Douat-Casassus, \& Pouysegu, 2011). This definition does not include low molecular weight structures, which have been shown to have potential benefits for human health. In practice, this means there is the use of a less strict definition of a polyphenol term that does not extend to low molecular weight structures. Consequently, there are several thousand compounds derived from plants that have higher biological potential, which have only one or more aromatic rings and at least two hydroxyl groups, are categorized as polyphenols (Sies, 2010).

Natural polyphenols are secondary metabolites derived from plants produced as defense agents against various types of stress, such as ultraviolet radiation, pathogen aggression, low soil fertility, changes in ambient temperature and drought (Dai \& Mumper, 2010; Manach, Scallbert, Morand, Remesy, \& Jimenez, 2004). Based on their chemical structure, there are four main classes of polyphenols: Phenolic acids, flavonoids, stilbenes, and lignans (Bravo, 1998; Manach et al., 2004). The knowledge and implications of these compounds on human health include their effects on cancer, (Guo, Kong, \& Meydani, 2009; Kampa, Nifli, Notas, \& Castanas, 2007; Korkina, Luca, Kostyuk, \& Pastore, 2009) nervous system protection, (Gutierez-Merino et al., 2011; Zhao, 2009) dysfunction and damage to the cardiovascular system, (Grassi et al., 2009; Sies, 2010) metabolic syndrome, (Agouni, Lagrus-Lak-Hal, Tesse, Mulder, \& al, 2009; Cherniack, 2011) diabetes, aging, and various inflammatory-related pathologies (Accomando, Pellitteri, \& Corsello, 2010; Milne et al., 2007; Queen \& Tollefsbol, 2010). Based on all these benefits, polyphenols have been used for thousands of years in traditional medicine in the eastern country. However, the inclusion of these compounds in western medicine remains a pending issue, perhaps because of little information so that its potential is not much scientifically known (Dashwood, 2007; Rodriguez, Estrela, \& Ortega, 2013).

Flavanol is one of the most important flavonoid subfamilies in human health. 33 Most natural flavanols are stereoisomers in cis or trans configurations with 2-3 carbon, profiles and relative concentrations depending on the type of original plant.33,80 For example, cocoa (Theobroma cocoa) synthesize most of the type B dimers, whereas most of the type A dimers are in the bean (Arachis hypogea L.). Chemically, the monomers of type B dimers are connected via $4 \rightarrow 8$ carbon-carbon bonds. In essence, a higher molecular weight oligomer present in cocoa maintains $4 \rightarrow 8$-type linearly rotating molecular bonding forces that is the most stable three-dimensional structure. In the form of an A-type dimer, the monomer is connected by both $4 \rightarrow 8$ carbon-carbon and bond $2 \rightarrow$ $\mathrm{O} 7$ ether bonds. In other plants such as tea (Camellia sinensis), flavanols may contain gallate groups (eg, (-) - epigallocatechin gallate, EGCG) and complex polymeric forms (tannins) (Dashwood, 2007; Fraga \& Oteiza, 2011).

Current cancer treatment strategies using a combination of targeted therapies, conventional chemotherapy or radiotherapy are considered more promising, and can provide greater efficacy and better survival.84 Nevertheless, malignant cells can find alternative survival mechanisms. Indeed, changes in conditions in tissue micro environments, systemic / intraorganic signals, immune cells or stressrelated cancer therapy may lead to altered proteomic / genome profiles in metastatic cells leading to either a mechanism of cancer cell suppression or survival. In this case natural polyphenols including isoflavones, flavanols, flavones, anthocyanins, catechins, flavanones and others have been shown to potentially inhibit carcinogenesis (Batra \& Sharma, 2013; Rodriguez et al., 2013; Song et al., 2014) Early reports suggest that polyphenols have a protective effect in the development of pulmonary neoplasia. In addition polyphenols are also able to inhibit proliferation of lung cancer proli cells and prevent metastasis with different mechanisms. It has been reported that 
polyphenols from tea and atorvastatin synergistically inhibit lunginduced lung tumorigenesis and prevent the growth of lung cancer cells H1299 and H460, which are thought to be increased by cell apoptosis. Other recent reports suggest that epicatechin enlarges the ability of curcumin to induce inhibition of growth and apoptosis in human lung cancer cells. Thus it shows that the ability of this polyphenol is very applicable in the treatment of lung cancer (G. Lu, Xiao, You, Lin, \& Jin, 2008; Saha, Kuzuhara, Echigo, Suganuma, \& Fujiki, 2010; Yuan, Chen, Fan, Tang, \& Yang, 2006). Natural polyphenols contained green tea, turmeric, red wine, and mulberry, have been shown to be effective in the treatment of metastatic prostate cancer that is resistant to therapy. In vitro studies show that the natural polyphenols are sensitive to LNCaP prostate cancer cells, via TRAIL mediated apoptosis, via extrinsic path modulation .89-91 Polyphenols can also induce apoptosis via intrinsic pathways in prostate cancer cell lines by activating caspases- 9 and -3 and Change the ratio of Bax / Bcl-2 (Benitez, Pozo-Guisado, Alvarez-Barrientos, FernandezSalguero, \& Castellón, 2007).

HepG2 cell line is a cell line derived from a tumor tissue of HCC sufferers that has grown on a large scale and is known to be appropriate as an in vitro model for studying intracellular activity, hepatic metabolism, xenobiotic toxicity, cytoprotective, hepatocarcinogenesis, and targeted therapeutic agents. At This study used the HepG2 cell line as an in vitro model to examine the therapeutic target of pure soursop leaf compounds on liver cancer cells.

\section{METHODOLOGY}

\section{Materials}

Materials used in this study was the pure compound isolated from the soursop leaves (Annona muricata) code SF-1603, HepG2 cell line (HB-8065TM) from the American Type Culture Collection (ATCC), Dulbecco's Modified Eagle Medium (DMEM ) containing 10\% fetal bovine serum (FBS), penicillin, streptomycin and trypsin for cell culture, as well as in situ Terminal deoxynucleotidyl Transferasemediated dUTP Nick End Labeling (TUNEL) Cell Death Detection Kit from Rosche and 3-4-5-dimetylthiazol-2yl-2,5-difenil tetrazolium bromide (MTT) kit.

\section{HepG2 Cell Line Culture}

HepG2 cell line used in this study were less than 15 passages. Cell were seeded into well in Medium (DMEM / F12) containing 10\% Fetal Bovine Serum, previously release cells using trypsin $0.05 \%$ EDTA $0,53 \mathrm{mM}$, then added to the growth medium into a cell suspension. The cells were counted using a hemocytometer and planted with a cell density of 25,000 cells $/ \mathrm{mL}$ and exposed with SF
1603 with dosage of $0,5 \mathrm{xIC}_{50}, \mathrm{IC}_{50}$ and $2 \mathrm{xIC}_{50}$ for 24,48 and 72 hour at $37^{\circ} \mathrm{C}$ with $5 \% \mathrm{CO} 2$ atmosphere.

There were control group and intervention group given SF-1603 with concentration of $0,5 \times \mathrm{IC}_{50}, \mathrm{IC}_{50}$ and $2 \mathrm{xIC}_{50} \mathrm{~mL}$. Determination of $\mathrm{IC}_{50}$ concentration was done using 3-4-5-dimetylthiazol-2yl-2,5difenil tetrazolium bromide (MTT) method.

\section{Apoptosis Detection by TUNEL Examination}

Methods for detecting cells undergoing apoptosis can be based on the characteristics of apoptosis itself that one of them is going on DNA fragmentation. A common method used to detect DNA fragmentation enzymatically by using TUNEL method. TUNEL reagent consisting of terminal transferase enzyme that served to identify the ends $3^{\prime} \mathrm{OH}$ (nick end) generated by DNA fragmentation and fluorescein-dUTP to visualize the end $3^{\prime} \mathrm{OH}$ observed using inverted microscope.

\section{Statistical analysis}

All qualitative data are representative of at least three independent experiments. Values are expressed as mean \pm SD. Statistical analyses were conducted using linear regression. The statistical package IBM SPSS Statistics 21 for Windows was used in the analysis.

\section{Implications of Ethical Aspects}

This study has obtained ethical approval from Medical Research Ethics Committee Medical Faculty Padjadjaran University No.988 / UN6.C2.1.2 / KEPK / PN.

\section{RESULTS AND FINDINGS}

Observation done using inverted microscope to visualize apoptotic cells comparisons with living cells. TUNEL only detect apoptotic cells and produces a purplish brown color, whereas living cells appered not stained. Count the number of apoptotic cells and living cells in each group with three replications. Picture of cells undergoing apoptosis in TUNEL staining can be seen in the following Fig 3.

The cells undergoing apoptosis was observed using inverted microscope at the $24^{\text {th }}$ hour, $48^{\text {th }}$ and $72^{\text {nd }}$, but at the $24^{\text {th }}$ hour and $48^{\text {th }}$ hour has not seen signs of cells undergoing DNA fragmentation. Signs of cells undergoing apoptosis seen in the $72^{\text {nd }}$ hour. Signs of apoptosis in each group were observed using inverted microscope can be seen in the pictures $4 \mathrm{a}-4 \mathrm{~d}$.

The cells that did not stain with not fill the entire base plate, there were empty areas in between. This indicates that living cells has been reduced, but the cells were stained purplish brown fewer than the number of cells not stained indicating the number of apoptotic cells less than a living cell. 

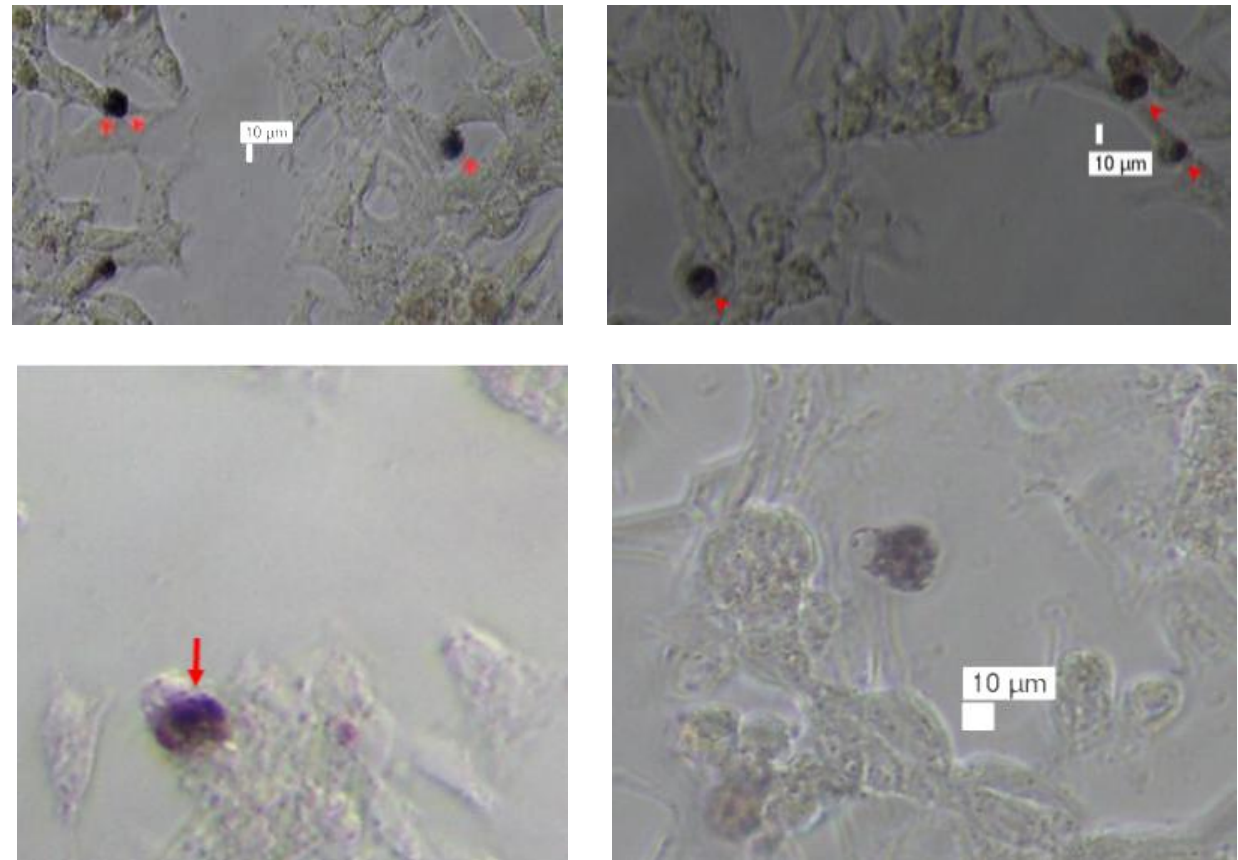

Fig. 3 TUNEL Result : Cells experiencing apoptosis looks purplish brown colored due to DNA fragmentation (red arrows), the living cells not stained.
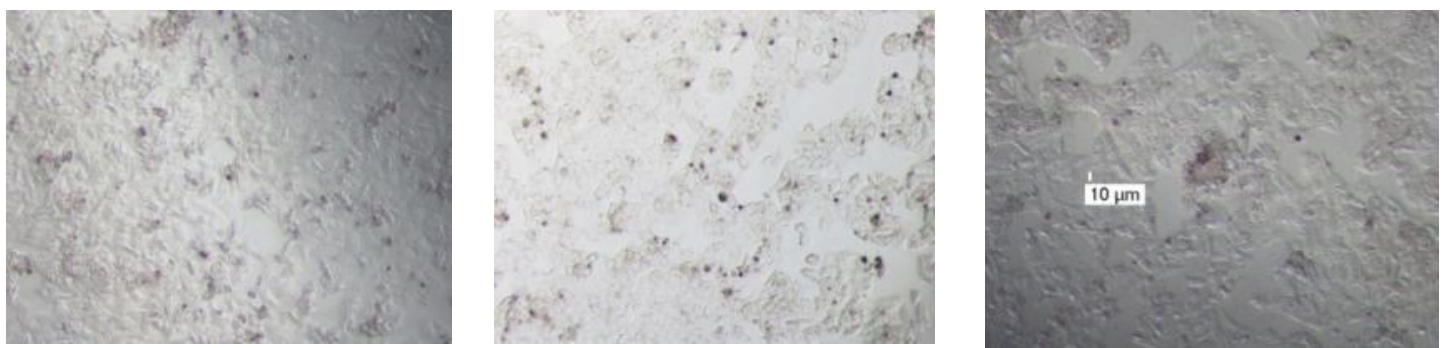

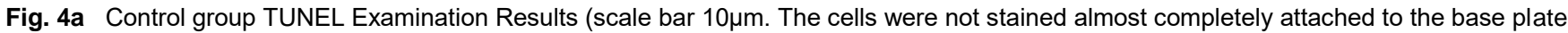
indicating the cells are still alive. Cells were stained purplish brown very slightly indicates very few cells undergoing apoptosis.
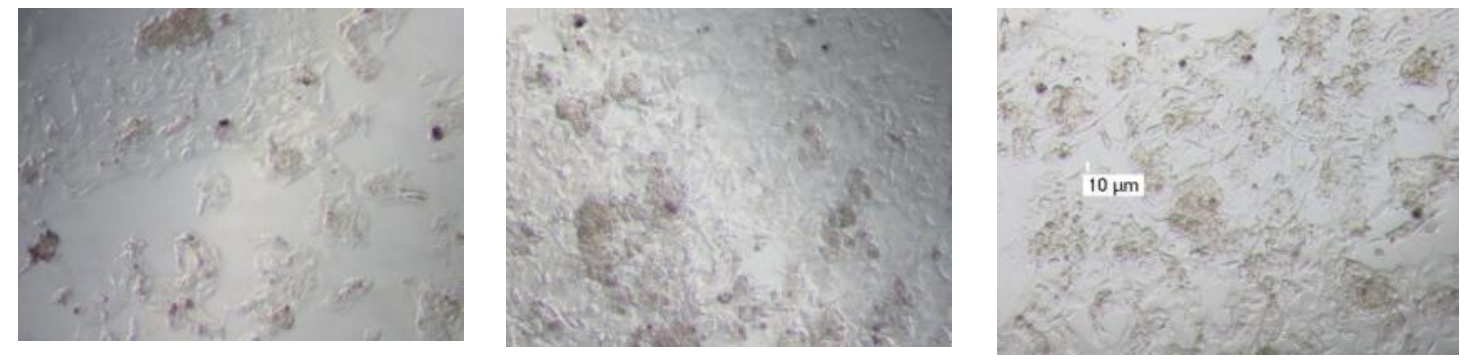

Fig. 4b Group I (0,5xIC 50$)$ TUNEL Examination Results (scale bar 10 $\mu \mathrm{m})$.
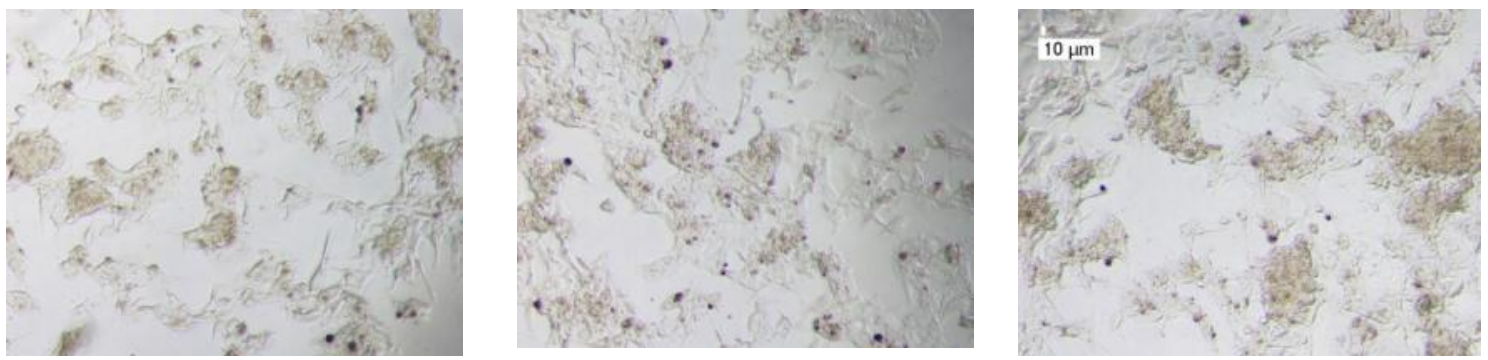

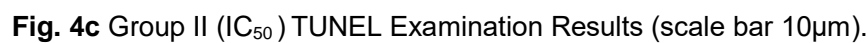



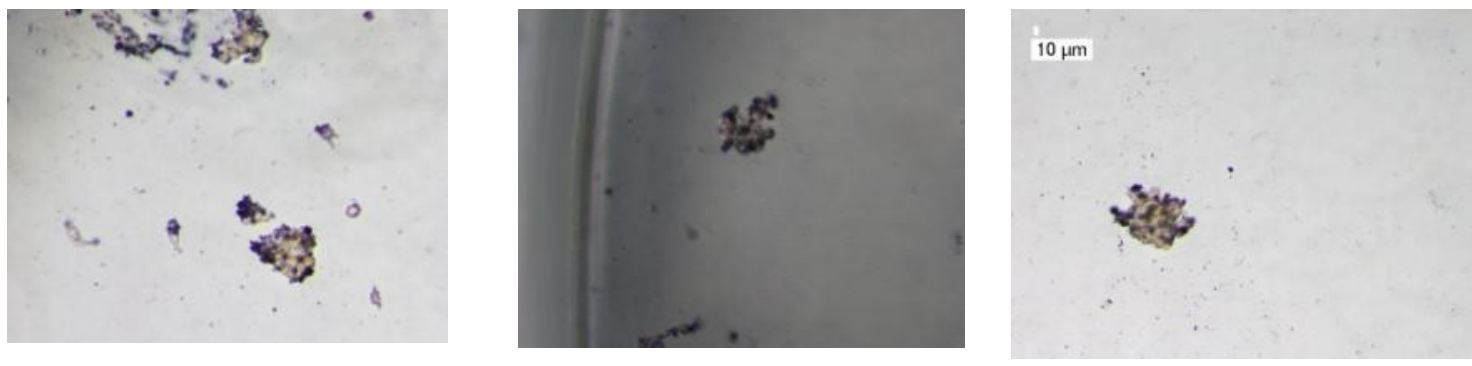

Fig. 4d Group III (2xIC 50 ) TUNEL Examination Results (scale bar 10 $\mu \mathrm{m})$.

More empty areas compared to the image of the cell. This indicates that living cells have very little. Looks pretty much purplish brown stained cells among cells that are not stained.

Virtually no cell attached to the base plate which indicates almost no living cells. Looked many floating cells and stained purplish brown indicating cells undergoing apoptosis.

\section{Apoptosis Index}

This study used a Raster Image software to count the number of cells. Calculation of value of apoptotic index is the number of cells undergoing apoptosis divided by the number of living cells. Value index of apoptosis in all groups can be seen in the following figure 5 .

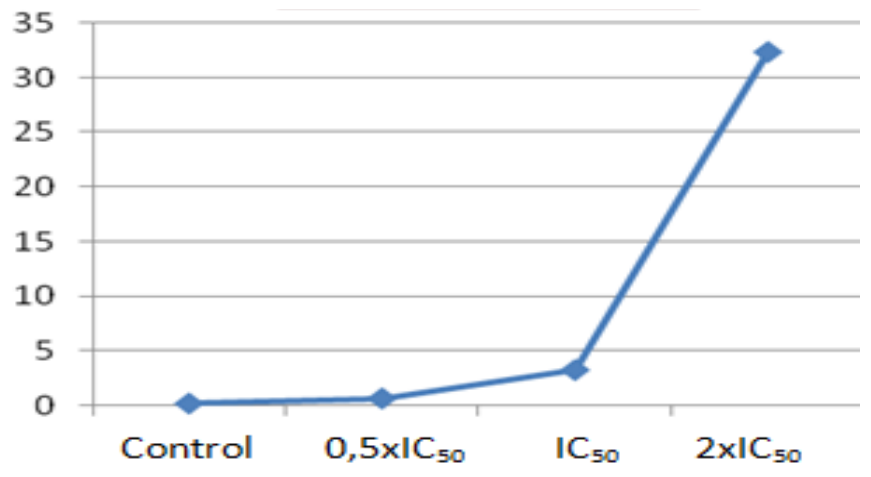

Fig. 5 Apoptosis index after giving SF-1603 in HepG2 Cell Line culture.

The chart in fig. 3 shows the value of apoptotic index increased along with the increase in the dosage of the compound SF-1603, with the highest index value apoptosis in a dose $2 \mathrm{xIC}_{50}$. To analyze the correlation between the dosage of pure compound soursop leaves SF1603 and the rate of apoptosis of HepG2 cell line culture, we carried out calculations using simple linear regression analysis. Based on the regression equation, there is a positive correlation between the rate of apoptosis and a dose of pure compound soursop leaves. The greater the dose administered, the rate of apoptosis will be higher with a correlation coefficient of 0.847 . This shows a very strong correlation level based on the interpretation of the correlation coefficient according to Guilford (see figure 6).

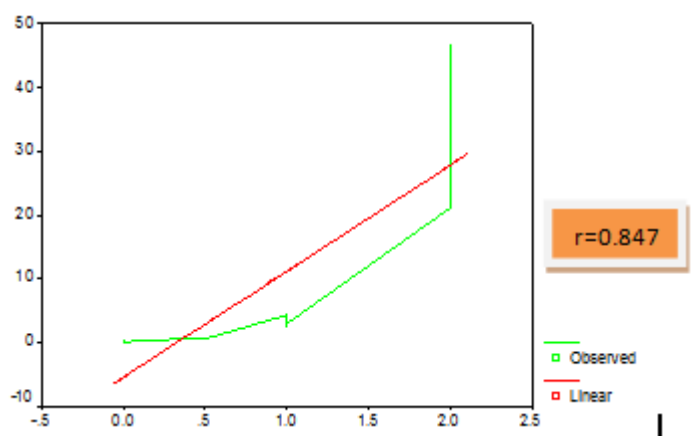

Fig. 6 Correlation between dosage of SF-1603 and apoptosis rate in HepG2 cell line culture.
This study showed that in all treatment groups were given SF-1603 compound there were apoptotic index value higher than the control group, which describes more cells undergoing apoptosis than living cells. The number of cells undergoing apoptosis increased along with increasing dose administration of SF-1603 compound. This analysis is reinforced by the results of linear regression tests which showed that there is a positive correlation between the amount of apoptosis and the dosage of the SF-1603 compound with a very strong correlation. Based on the analysis and statistical evidence, it can be concluded that a soursop leaves pure compound (SF-1603) has a strong ability to induce apoptosis, and the greater the dose of the SF-1603 compound is given, the more the amount of apoptosis occures, in HepG2 cell line culture. So this study showed that soursop leaves active compound (SF-1603) reflected to have apoptotic effect with a dosedependent manner and in a typical time course.

Apoptosis process is a series of processes that are long enough and require sufficient time to arrive at the final stage of DNA fragmentation due to DNAase activation. Both extrinsic and intrinsic pathways will then show a convergent point which causes the caspase enzymes to control subsequent processes. Proteins or molecules such as FAS, Bcl-2 and IAP play a role in signal transduction in the initiation phase that stimulates the activation of protease enzymes Caspase in the next phase of the execution phase that ended DNA fragmentation.(Rodriguez et al., 2013) To prove that the initiation process is optimal enough to stimulate the phase of execution that ends DNA fragmentation, it is necessary to perform an examination to detect DNA fragmentation in apoptotic cells. A common method used to detect enzymatic DNA fragmentation is to use the TUNEL method as used in this study which is then observed using inverted microscopy.

The results of the TUNEL examination in this study showed that DNA fragmentation seen in cell preparations in the form of purplish brown color was detected at 72 hours at all doses of SF-1603 compound. This is consistent with the literature which states that cell morphology undergoing apoptosis runs in time sequence with the initial process occurring in a fast time, while the final stage involving lysosomal degradation and DNA fragmentation usually only occurs completely in a longer time.(Martin, 2006; Wong, 2011)

\section{CONCLUSION}

It was concluded that the new soursop leaves active compound (SF-1603) is a powerful anticancer and had the ability to induce apoptosis on HepG2 cell line culture, so it can be used as a candidate for new agent of HCC therapy. This study also showed that soursop leaves active compound (SF-1603) reflected to have apoptotic effect with a dose-dependent manner and in a typical time course.

\section{ACKNOWLEDGEMENT}

This research was made possible thanks to the full support of the Faculty of Medicine, Bandung Islamic University and Faculty of Medicine Padjadjaran University, as well as with the cooperation of the Chemistry Research Laboratory Graduate School of Science, Padjadjaran University and Biotechnology Laboratory Rajawali Hospital Bandung. 


\section{REFERENCES}

Accomando, S., Pellitteri, V., Corsello, G. 2010. Natural polyphenols as anti inflammatory agents. Fornt Biosci, 2, 318-331.

Adewole S. O., Ojewole, J., A. 2008. Protective effects of annona muricata linn. (annonaceae) leaf aqueous extract on serum lipid profiles and oxidative stress in hepatocytes of streptozotocin-treated diabetic rats. African journal of traditional, complementary and alternative medicines, 6, 1, 30-41.

Adina, A., Handoko, F., Setyarini, I., Septisetyani, Riyanto, S., Meyranto, E. 2009. Ekstrak etanolik kulit jeruk nipis (citrus aurantifolia (cristm.) swingle) meningkatkan sensitivitas sel mcf-7 terhadap doxorubicin. Kongres ilmiah ISFI ke-16, Yogyakarta, Indonesia, 55-62

Agouni, A., Lagrus-Lak-Hal, A., Tesse, A., Mulder, P., et al. 2009. Red wine polyphenols prevent metabolic and cardiovascular alterations associated with obesity in zucker fatty rats $(\mathrm{Fa} / \mathrm{Fa})$. PLos One, 4, e5557. (rev)

Albert B, Johnson A.Lewis J, Morgan D, Raf M, 2015. Molecular biology of the cell. Edisi ke-4. New York (6 ed.). New York: Garland Science Taylor and Francis Group Company.

Baharvand, A., Ali, R., Yusof, A. M., Ibrahim, A. N., Chandren, S., Nur, H. 2014. Preparation of anatase hollow $\mathrm{TiO}_{2}$ spheres and their photocatalytic activity in the photodegradation of chlorpyrifos. Journal of the Chinese Chemical Society, 61, 11, 1211-1216.

Bassiouny, A., Bassiouni, N., Nosseir, M., Zoheiry, M., El-Ahwany, G., et al. 2008. Circulating and hepatic fas expression in hcv-induced chronic live disease and hepatocellular carcinoma. Medscape Journal of Medicine, 10, 6, 130.

Batra, P., Sharma, A. K. 2013. Anti-cancer potensial of flavonoids: Recent trends and future perspective. 3Biotech, 3(6), 439-459.

Benitez, D., Pozo-Guisado, E., Alvarez-Barrientos, A., Fernandez-Salguero, P. Castellón, E. 2007. Mechanisms involved in resveratrol-induced apoptosis and cell cycle arrest in prostate cancer-derived cell lines. Journal of Andrology, 28, 282-293.

Bravo, L. 1998. Polyphenols: Chemistry, dietary source, metabolism and nutritional significance. Nutrition Reviews, 56, 317-333.

Bruix, J., Sherman, M. 2005. Management of hepatocellular carcinoma. Journal of Hepatology, 42, 5, 1208-1236.

Cagle, P., Allen, T. 2009. Apoptosis. In Basic concept of molecular pathology (pp. 32-38): Springer Dordrecht Heidelberg.

Cardoso, A., Moucari, R., Mendes, C., Ripault, M., Giully, N., Castelnau, C. 2010. Impact of peginterferon and ribavirin therapy on hepatocellular carcinoma: Incidence and survival in hepatitis $c$ patients with advanced fibrosis. . Jjhep, 52, 652-657.

Cha, C., DeMatteo, R. 2005. Molecular mechanisms in hepatocellular carcinoma development. Practise \& Research Clinical Gastroenterology, $19,1,25-37$.

Chang, Y., Xu, Y. 2000. Expression of BCL-2 inhibited fas-mediated apoptosis in human hepatocellular carcinoma BEL-7404 cells., Cell Research, 10 (3), 233-242.

Cherniack, E. 2011. Polyphenols: Planning the seeds of treatment for the metabolic syndrome. Nutrition, 27, 617-623.

Chiu, H., Chih, T., Hsian, Y., Tseng, C., Wu, M., Wu, Y. 2003. Bullatacin, a potent antitumor annonaceous acetogenins, induces apoptosis through a reduction of intracellular camp and cgmp levels in human hepatoma 2.2.15 cells. Biochemical Pharmacology, 65, 3, 319-327.

Coloma, A., Guadan-o, A., Ine'sa, C., Martinez-Diazb, R., Cortesc, D. 2002. Selective action of acetogenin mitochondrial complex $\mathrm{i}$ inhibitors. $Z$ Naturforsch, 57C, 1028-1034.

D’Archivio, M., Santangelo, C., Scazzocchio, B., Varì, R., Filesi, C. 2008 Modulatory effects of polyphenols on apoptosis induction: Relevance for cancer prevention. International Journal of Molecular Sciences, 9, 213-228.

Dai, J., Mumper, R. 2010. Plant phenolics: Extraction, analysis and their antioxidant and anticancer properties. Molecules, 15, 7313-7352.

Dashwood, R. 2007. Frontiers in polyphenols and cancer prevention. Journal of Nutrition, 37, 267S-269S.

Fajarningsih, N., Nursid, M., Wikanta, T., Marraskuranto, E. 2008 Bioaktivitas ekstrak turbinaria decurrens sebagai antitumor serta efeknya terhadap proliferasi limfosit. Jurnal Pascapanen dan Bioteknologi Kelautan dan Perikanan, 3, 1.

Fraga, C. G., Oteiza, P. I. 2011. Dietary flavonoids : Role of (-)-epicatechin and related procyanidins in cell signaling. Free Radical Biology \& Medicine, 51, 813-823.

Ghassan, K., Abou-alfa, M. Huitzil-Melendez FD, Saltz L. 2007. . Current and novel therapeutics for hepatocellular carcinoma (American society of Clinical Oncology). Gastrointest Cancer Research 2(2).

Grassi, D., Desideri, G., Groce, G., Tiberti, S., Anggio, A., et al, 2009. Flavonoids, vascular function and cardiovascular protection. Current Pharmaceutical Design, 15, 1072-1084.

Guo, W., Kong, E., Meydani, M. 2009. Dietary polyphenols, inflammation and cancer. Nutrition and Cancer, 61, 807-810.
Gutierez-Merino, C., Lopez-sanchez, C., Lagoa, R., Samhan-Arias, A., Bueno, C., al, e. 2011. Neuroprotective actions of flavonoids. Current Medicinal Chemistry, 18, 1195-1212.

Hanahan, D., Weinberg, R. 2000. The hallmarks of cancer. Cell, 100, 57-70.

He, H., Wu, X., Yu, B., Liu, K., Zhou, G., Qian, G., et al. 2010. The effect of desacetyluvaricin on the expression of TLR4 and P53 protein in Hepg 2.2.15. Journal of Hepatitis, 11, 5, 364-367.

Ho, H., Pok, S., Streit, S., Ruhe, J., Hart, S., Lim, K., et al. 2009. Fibroblast growth factor receptor 4 regulates proliferation, anti-apoptosis and alphafetoprotein secretion during hepatocellular carcinoma progression and represents a potential target for therapeutic intervention. Journal of Hepatology, 50, 118-127.

Huynh, H., Ngo, V., Koong, H., Poon, D., S, S. C., Toh, H., et al. 2010. Azd6244 enhances the anti-tumor activity of sorafenib in ectopic and orthotopis models of hcc. Journal of Hepatology, 52, 79-87.

Irene, M., Ghobrial, M., Thomas, E., Witzig, M., Alex, A., Adjei, M. 2005. Targeting apoptosis pathways in cancer therapy. CA: A Cancer Journal for Clinicians, 55, 178-194.

Kampa, M., Nifli, A., Notas, G., Castanas, E. 2007. Polyphenols and cancer cell growth. Reviews of Physiology, Biochemistry and Pharmacology, 159, 79-113.

Korkina, L., Luca, C. D., Kostyuk, V., Pastore, S. 2009. Plant polyphenols and tumors: From mechanism to therapies, prevention and protection againts toxicity of anti-cancer treatments. Current Medicinal Chemistry, 16, 3943 3965.

Kumar, V., Cotran, R., Robbin, S. 2003. Pathologic basic of disease (7 ed.). Philadelphia: Saunders-Elsevier.

Lee, S., Shin, M., Lee, H., Bae, J., Lee, K., H, K., et al. 2001. Expression of fas and fas-related molecules in human hepatocellular carcinoma. Human Pathology, 32, 3, 250-256.

Lencioni, R., Crocetti, L., Petruzzi, P., Vignali, C., Bozzi, W., C, C. P., et al. 2008. Doxorubicin-eluting bead-enhanced radiofrequency ablation of hepatocellular carcinoma:A pilot clinical study. Journal of Hepatology, 49, 217-222.

Liu, Q., Chen, J., Liu, L., Zhang, J., Wang, D., Ma, L., et al. 2011. The x protein of hepatitis b virus inhibits apoptosis in hepatoma cell through enchancing the methionine adenosyltransferase $2 \mathrm{a}$ gene expression and reducing s-adenosylmethionine production. The Journal of Biological Chemistry, 286, 19, 17168-17180.

Lu, G., Xiao, H., You, H., Lin, Y., Jin, H. 2008. Synergistic inhibition of lung tumorigenesis by a combination of green tea polyphenols and atorvastatin. Clinical Cancer Research, 14, 4981-4988.

Lu, X., Lee, M., Tran, T., Block, T. 2005. High level expression of apoptosis inhibitor in hepatoma cell line expressing hepatitis B virus. International Journal of Medical Sciences, 2, 1, 30-35.

Manach, C., Scallbert, A., Morand, C., Remesy, S., Jimenez, L. 2004 Polyphenols: Food sources and bioavailability. American Journal of Clinical Nutrition, 79, 727-747.

Martin, K. R. 2006. Targeting apoptosis with dietary bioactive agents. Experimental Biology and Medicine, 231, 117-29.

Tejasari, Sastramihardja, HS., Abdurachman SA, Prasetyo D. 2016. SF-1603; soursop leaves new active compound. A candidate for hepatocellular carcinoma therapy on fas as a new molecular target. Paper presented at the The 3rd Asia Future Conference, Kitakyushu-Japan (29 sept-3 oct), Proceeding Digital ISSN 2432-0528.

Tejasari, Shahib N., Sastramihardja HS, Iwan D. 2014. The role of soy in preventing apoptosis in liver injury. International Journal of Research in Pharmaceutical and Nano Science, 3, 5, 373-379.

Milne, J., Lambet, P., Schenk, S., Carney, D., Smith, J., al, e. 2007. Small molecule activators of sirt 1 as therapeutics for the treatment of type 2 diabetes. Nature 450, 712-716.

Muharni, Supriyatna, Husein, H., Bahti, Dachriyanus. 2009. Phenolic compound from the stem bark of manggis hutan (garcinia bancana miq.) and their antioxidant acctivity. Indonesian Journal of Chemistry., 9 (2), 321 327.

Park, S., Lee, Y., Han, S., Kwon, S., Kwon, O., Kim, S., et al. 2006. Systemic chemotherapy with doxorubicin, cisplatin and capecitabine for metastatic hepatocellular carcinoma. BMC Cancer, 6, 3, 10.1186/1471-2407-11861183.

Queen, B., Tollefsbol, T. 2010. Polyphenols and aging. Current Aging Science, 3, 34-42.

Quideau, S., Deffieux, D., Douat-Casassus, C., Pouysegu, L. 2011. Plant pholyphenols: Chemical properties, biological activities and synthesis. Angew Chem Int Ed Engl. 50(3). 582-621.

Robotin, M., Kansil, M., Howard, K., George, J., Tipper, S., Dores, G., et al. 2009. Antiviral therapy for hepatitis b-related cancer prevention is more cost-effective than cancer screening. Journal of Hepatitis, 50, 990-998.

Rodriguez, M. L., Estrela, J. M., Ortega, A. L. 2013. Natural polyphenols and apoptosis induction in cancer therapy. Journal of Carcinogenesis and Mutagenesis, S6, 004. 
Saha, A., Kuzuhara, T., Echigo, N., Suganuma, M., Fujiki, H. 2010. New role of (-)-epicatechin in enhancing the induction of growth inhibition and apoptosis in human lung cancer cells by curcumin. Cancer prevention Research, 3, 953-962.

Sherman, M., Burak, K., Maraun, J., Metrakos, P., Myers, R., Guindi, M., et al. 2011. Multidiciplinary canadian concensus recommendations for the management and treatment of hepatocellular carcinoma. Current Oncology, $18,5,228-240$.

Sies, H. 2010. Pholyphenols and health: Update and perspectives. Archives of Biochemistry and Biophysics, 501, 2-5.

Song, Y., Zhang, A., Yan, G., Han, Y., Wang, X. 2014. Pant-derived natura products as leads to anti-cancer drugs. Journal of Medicinal Plant and Herbal Therapy Research, 6, 15.

Spengler, U. 2012. Diagnosis, prognosis \& therapy in hepatology. In Hepatology a Clinical Textbook (pp. 302-312): Flying Publisher. USA

Steeg, P. 2006. Tumor metastasis: Mechanistic insights and clinical challenges. Nature Medicine, 12, 895-904.

Tejasari, M., Shahib, N., Iwan, D., Sastramihardja, H. S. 2013. Peran kedelai (glycine max 1.) dalam pencegahan apoptosis pada cedera jaringan hati. Global Medical \& Health Communication, 2, 1, 15-20.

Thorgeirsson, S., Grisham, J. 2002. Molecular pathogenesis of human hepatocellular carcinoma. Nature Genetics, 31.

Wirth, T., Kuhnel, F., Fleischmann-Mundt, B., Woller, N., Djojosubroto, M., Rudolph, K., et al. 2005. Telomerase-dependent virotherapy overcomes resistance of hepatocellular carcinomas against chemotherapy and tumor necrosis factor-related apoptosis-inducing ligand by elimination of MCL-1 Cancer Resarch Journal 65, 7393-7402.

Wong, S. R. 2011. Apoptosis in cancer: From pathogenesis to treatment Journal of Experimental \& Clinical Cancer Research, 30(87), 30, 87.

Wu, F., Zeng, L., Gu, Z., Zhao, G., Zhang, Y., Schwedler, J., et al. 1995. New bioactive monotetrahydrofuran annonaceous acetogenins, annonamuricin $C$ and muricatocin $C$, from leaves of annona muricata. Journal of Natural Products, 58, 6, 909-915.

Yildiz, L., Baris, S., Aydin, O., Kefeli, M., Kandemir, B. 2008. BCL-2 positivity in $B$ and $C$ hepatitis and hepatocellular carcinoma. Hepatogastroeneterology, 55, 88, 2207-2210.

Yuan, Z., Chen, L., Fan, L., Tang, M., Yang, G. 2006. Liposomal quercetin efficiently suppresses growth of solid tumors in murine models. Clinical Cancer Reseacrh Journal, 12, 3193-3199.

Yuniarti, L., Sastramihardja, H., Purbaningsih, W., Tejasari, M., Respati, T., Hestu, E., et al. 2014. Soursop effect in cervical cancer apoptosys mechanism. Global Medical \& Health Communication, 2, 1, 6-14.

Zhao, B. 2009. Natural antioxidant protect neuron in alzheimers disesase and parkonsons disease. Neurochemical Research, 34, 630-638. 